\title{
Attitude towards Safe Driving Scale (ASDS-46) as a Predictor of Young Adult Quality Of Life
}

\author{
Mohamad Ghazali Masuri, Akehsan Dahlan, \\ Ajau Danis, Khairil Anuar Md Isa \\ Faculty of Health Sciences, \\ Universiti Teknologi MARA Puncak Alam Campus, 42300 Selangor, Malaysia \\ zalie222@gmail.com
}

\begin{abstract}
Driving is an essential component in our daily life and it relationships with quality of life (QoL) shows very limited evidence. The aim of this study is to develop an assessment scale related with the driving attitude among Malay young adult from all over Malaysia, which had multiple socio-demographic backgrounds. The validity and reliability test for item and person value using Rasch model shows .80 , followed by .84 Cronbach's Alpha value. This study would strongly recommend that the use of Attitude towards Safe Driving Scale (ASDS) has a great potential as a predictor to understand human respond and their QoL.
\end{abstract}

Keywords: Educated young adult; road traffic accident; quality of life; attitude scale

eISSN 2398-4279 @ 2018. The Authors. Published for AMER ABRA cE-Bs by e-International Publishing House, Ltd., UK. This is an open access article under the CC BY-NC-ND license (http://creativecommons.org/licenses/bync-nd/4.0/). Peer-review under responsibility of AMER (Association of Malaysian Environment-Behaviour Researchers), ABRA (Association of Behavioural Researchers on Asians) and cE-Bs (Centre for EnvironmentBehaviour Studies), Faculty of Architecture, Planning \& Surveying, Universiti Teknologi MARA, Malaysia. 


\subsection{Introduction}

Driving play an important role in our life as people travel from one place to another place by using several mode transportation such as personal or public transportation. This makes traveling become a very important aspect in the quality of life (QOL). As an occupational therapist, we were involved in educating, promote, evaluate, modify and rehabilitate people to become an Independence individual since driving can be part of the important component in the occupational performance area. This topic is relevant to the occupational therapist with regards of the profession itself as a health prevention, health promotion, and health education. This study was conducted among UiTM Puncak Alam students population, and the results will be able to explain the perception of educated young adult drivers in Puncak Alam towards speeding and associated risk. The results could be used to provide information to the targeted population regarding the issues. Hence appropriate intervention and strategies can be planed to reduce the road crashes. Thus, from this study, the outcomes of this study will give benefits to the people and country so that the accidents rate can be decreased and save more life.

Road traffic accident (RTA) will give a huge impact to the individual and communities that include socio life, economic and also may cause damage to the property. The impact of the road traffic accident to the person may be fatal or non-fatal injuries that may lead to disability. Road traffic accident will cause a lost to country due to the government need to spend the money for the cost of treatment and rehabilitation for the injured person. Therefore, a proactive measure needs to take account to reduce the rate of road traffic accident. This present study will identify the prevalence use of text messaging while driving among young adults and their risk perception towards that's behavior. Road traffic accident has become a great issue and health problem in worldwide. Currently ranked eight, it has been estimated that by 2030 road traffic accident will become the fifth leading cause of death in the world. According to World Health Organization, (2013), over 1.2 million people die annually on the world's road and between 20 and 50 million sustain non-fatal injuries due to road traffic crash. Based on research conducted by the University of Michigan, "Malaysia was ranked as the top of 25 most dangerous countries in the world road accident", with estimated that 30 fatalities per 100,000 individual (The Star, 2014). Besides, the number of the road accident and fatalities are an increase compared with last year in 2014 with 1557 people involve in the road accident, and 1696 were killed (Official Portal of Royal Malaysia Police, 2015). This high number of the road accident is quite worrying as this death and injury will give the negative impact on the family, community and also the country. These numbers of injuries keep arising every year and had become a frightening issue in health and may contribute to significant effect on people quality of life (Wan Ahmad Kamal, Masuri, Dahlan, \& Md Isa, 2015).

RTA frequently involves multi-level society, and this has become a demanding community issue where more serious participation is needed to improve driver's attitude in the future. RTA has a significant impact on quality of life and financial burden to the government and Malaysian society. The number of road traffic accidents among young adult is an alarming issue in Malaysia. Malaysian governments through relevant agencies have 
worked very hard to enforce all relevance acts related to it. One of the prime government objectives is to ensure safer Malaysian drivers in the future. To date, there were still a limited number of local research and evidence supporting the elements of driver's attitudes and behavior analysis had been conducted.

\subsection{Literature Review}

Driving is one of the most critical activities of daily living that involves the active eye, hand, and foot coordination. Drivers that is not proficient or fail to organize and interact with their vehicle and surrounding environment may lead to road traffic injury (RTI) (Masuri, Md Isa, \& Mohd Tahir, 2012). This interaction could play a major role in preventing and predicting future studies. The majority of road traffic accidents were caused by human error. This made the drivers' error as an important human component that need to be further investigated. These road injuries and fatalities have become a great concern for the Malaysian government. This scenario may be due to rapid development in Malaysia (Mohamad Ghazali Masuri, Akehsan Dahlan, Ajau Danis, \& Khairil Anuar Md Isa, 2015). This rapid development contributed to the increasing number of vehicle on the road that could potentially increase the possibilities of RTA. There were many causes of an accident either it is due to primary or secondary factors. Factors such as speeding, using a mobile phone and not wearing a seat belt are considered as a contributing factor for injury and fatality (Mohamad Ghazali Masuri, Akehsan Dahlan, Ajau Danis, \& Khairil Anuar Md Isa, 2015; Md Isa et al., 2012).

Many studies have proven that attitudes rarely present the synchronize behavior. Attitudes can be presented either in a positive or negative form. Even though attitude and behavior were not usually straightforward, and they are sensitive according to the social situation, but, attitude assessment can be used to predict future behavior (Iversen, 2004). Understanding of human attitudes relates with driving behaviors were very critical to developing more appropriate planning and intervention in reducing the prevalence of RTA. At present, there was limited evidence available to justify which human components were needed to be addressed. Previous study shows that, different factors such as sociodemographic issues (Al-Naggar, Bobryshev, \& Mohd Noor, 2013), socioeconomic status (Masuri, Md Isa, \& Mohd Tahir, 2012), age/gender (Scott-Parker, Watson, King, \& Hyde, 2012), education level (Masuri, Md Isa, Mohd Tahir, et al., 2012) and living status (Al-Naggar et al., 2013) brought significant effects on driving behaviour.

Speeding behavior among young adult in Malaysia frequently involves stimulation from our society. This behavior has become a demanding community issue where more serious community participation is needed to improve the future of young drivers. It is important to understand that, the stimulation that involve which contributed to risk-taking behavior among young drivers is usually beyond our control. It was a little unfair to depend solely only on the government to improve the drivers' behavior and their quality of life. Public participation such as parents, teachers and the most important thing; participants circle of friends, is to a large extent were needed in shaping a better future in the road and transportation system in Malaysia. A deeper understanding of the young drivers' behavior is needed to enhance the plan for preventive measures. For example the study on the differences of the belief among 
the high and low intender to speed by Forward, (2009) and Horvath et al., (2012a). Similarly, a study finding on the belief influencing drivers' hands-free and hand-held mobile phone use (White et al., 2010; Zhou et al., 2009). Such study finding can guide more relevant road safety solutions to encourage the safer road user behavior, especially among the young adult nowadays. In future, to understand this situation, we must gain a deeper understanding of the beliefs underlying behind the driver's intention to speed for both genders. The finding of this study also suggested the intention speed was caused by the pressure from the peer (or familiar person). By promoting safe behavior on the road for changing the views of the driver, it was predicted to have the capability to prevent RTA. Also, the result of this study could provide a good insight for the government, related agencies, and mass media to promote better road safety in future. Moreover, the other implication of this research was it can help Government to plan a more cost-effective campaign. The slogan such 'first class facility, this class mentality' should be changed to suit the status of developing the country by the year 2020. This evaluation could be used in screening and re-evaluation process of licensing in Malaysia. This evaluation also will be able to help the government in producing a better road society in the future. In summary, the current study concluded that correct stimulation while driving could help drivers to change their intention to speed. This behavior changes is important where it will be able to reduce the potential for accident and has an indirect effect on saves people life and increase the quality of life.

According to Scott-Parker, Hyde, Watson, and King (2012), individual aged 25 years old and below were considered as young drivers that frequently novices that are new to the driving experiences. A previous study had reported the percentage of young adult driver age between 17 and 24 commit traffic violations. The age group of the driver that strongly support the traffic violation countermeasure and moderate view toward traffic rule compliance was an older drivers that aged 65+ (Vardaki \& Yannis, 2013). Speed over the limit was found to be one of the major causes of this accident. With regards to speeding behavior, there were many human components that usually become significant variables that need to be investigated. It created a lot of debates among society. However, there has been limited to work on this issue in Malaysia.

In committing road violation, the previous study showed strong evidence that one of the factors contributing off the violence action were influences from a lot of internal and external stimulus including their sociodemographic characteristics. For example, some studies had claimed that, novice drivers demonstrate higher risky driving behavior compared to an older driver, and they were also found to be the highest number that involve with road crashes. According to National Highway Traffic Safety Administration, driver distraction contributes to the road traffic accidents that related to deaths and injuries, especially the younger driver, which 13 percent of drivers in a fatal distraction-affected accident who are under age 20 (Schroeder, Meyers, \& Kostyniuk, 2013). Therefore, these phenomena could be used as a reference in developing intervention about safety awareness and road safety campaign among young adult.

\subsection{Methodology}


For the last few years, a group of researcher under traffic research and cognitive ergonomics (TRACE) from Universiti Teknologi MARA, have extensively conducting a research in understanding drivers attitude. One of the TRACE objectives is to develop a deep understanding of driver's behavior, cognitive respond and their relations towards the quality of life. This study had involved series of data collection regarding drivers attitude among young adult in Klang Valley. This study had used Protection Motivation Theory (PMT) as an intervention model in the safe driving campaign. During the first stage of study design, the adapted question, based on Melamed, Rabinowitz, Feiner, Weisberg, \& Ribak (1996), was developed. This idea was used as a basic guideline during mind mapping process. It emphasized five factors addressed by PMT which are: Perceived susceptibility, Perceived severity, Perceived barriers, Perceived effectiveness and Perceived efficacy. This study also adapts some components from the Health Belief Model. At the very beginning, the in-depth interview was conducted among young adult. From that interview, the data was translated into few main themes and later the questionnaire was develop based on that themes. The main highlight of the interview results was three super theme, and they are the intention, opportunity, and space. Previous research also had highlighted few other main and subthemes. With using these themes as a guideline, a set of 46 questions were carefully developed and known as ASDS. The original version of this questionnaire is in Bahasa Malaysia. As previously discussed in another research report, to maintain the questionnaire in the original common language is important. This will help the respondent to understand the language; point highlighted as well as the meaning of the questions itself.

The first stage of validation of this questionnaire involving Rasch analysis. The analysis released that the item and person validity is at level .80. To confirm the reliability of ASDS, the second test was conducted. A cross-sectional study of convenience sample (undergraduate student) resides from Universiti Teknologi Mara, Kampus Puncak Alam was conducted. This study only included volunteered student who is having provisional or open driving license and aged range in between 17-25 years old. The questionnaire consists of two sections. Section 1 of the questionnaire consists of 22 demographic data that should be fulfilled by the respondent. The demographic data includes gender, age, faculty, and course, the level of education, driving licensed held (month), type of licensed, lifetime mileage, average minutes driving per week, frequency involves in a traffic accident and the rate of participation in speeding behavior for the past three months. Section 2 of the questionnaire contains 46 questions. These 46 items cover all of the main and sub-themes that were discovered during previous research. Before research implementation, the ethical clearance was gathered from Faculty of Health Science and Committee Research Centre (CRC), Universiti Teknologi Mara.

\subsection{Findings and Discussions}

A total of $14(18.7 \%)$ male and $61(81.3 \%)$ female, young novice driver from Universiti Teknologi Mara, Kampus Puncak Alam aged between 20-24 years take part in this study. Most of the participation aged range from 22-24 years old and holding open licensed (held licensed more than two years). Reliability test shows that the Cronbach's Alpha value for 46 
items is .839 , and this shows that, the assessment has very high reliability. The full version of questionnaire refers to appendix A.1. Table 1 shows the details of participants demographic data (Gender, age, area of living, types of traffic offenses, driving licensed held, mileage per year and history of involved in an accident). A total of 115 questionnaires was distributed, and only 75 (83\%) participants had returned the complete the questionnaire

Table 1: Demographic data

\begin{tabular}{ll}
\hline \multicolumn{1}{c}{ Characteristic (N=75) } & $\begin{array}{l}\text { Frequency } \\
\text { (percentage) }\end{array}$ \\
& \\
\hline Gender & $14(18.7)$ \\
Male & $61(81.3)$ \\
Female & \\
\hline Age & $31(41.4)$ \\
20-21 & $44(58.6)$ \\
22-24 & \\
\hline Area of living & $37(49.3)$ \\
Urban & $29(38.7)$ \\
Rural & $9(12.0)$ \\
Others & \\
\hline RTA offences (Yes answer) & $40(53.3)$ \\
Speeding & $40(53.3)$ \\
Against red light & $35(46.7)$ \\
Safety belt & $31(41.3)$ \\
Mobile phone & $29(38.7)$ \\
Carelessness & $18(24.0)$ \\
Double line & $16(21.3)$ \\
Overtaking queue & $10(13.3)$ \\
Signalling & $9(12.0)$ \\
Emergency lane & $3(4.0)$ \\
No respect to other drivers & \\
\hline Driving licensed held (months) & $17(22.7)$ \\
1-24 & $36(48.0)$ \\
25-60 & $8(10.7)$ \\
61-96 & $11(14.7)$ \\
97-120 & \\
\hline Lifetime mileage (km per year) & $64(85.3)$ \\
<10,000 & $4(5.3)$ \\
10,000-30,000 & $4(5.3)$ \\
>30,000 & $3(4.0)$ \\
Others & \\
Involve in traffic accident & $57(76.0)$ \\
Yene & $17(22.7)$ \\
\hline & \\
\hline & \\
\hline & \\
\hline
\end{tabular}

\subsection{Conclusion}

The end goal of this study is to produce practical program at the same time making a different in participants' health behavior, health, and quality of life. Producing a comprehensive intervention is a very challenging process. It required a high level of mental process that 
sometimes challenges existing theory. In common practice, health message designers often do not follow theories. They normally produce a message that concentrates on a few elements that are required for changing an audience's attitudes and behaviors, However, as a health professional, it is very critical to be able to plan interventions program and apply theories of health behavior. The ASDS did covers component of severity, motivation, and efficacy. These components have a positive impact on four kinds of issues; values, attitudes, drives and emotional states. It is a quite interesting concept that is relevant to be further discussed, but more research is needed in this field. Finally, by using appropriate evaluation framework, the chances of successful developed/implemented program will be increased. This study believed has a promising effect on helping to increase public awareness about the severity of driving behavior and the implication on their quality of life. Perhaps, the impact of this intervention can be increased by mutual supports from community and parents. As a conclusion, ASDS and components of PMT could give a significant feedback in understanding driver behavior and potential QoL issues. The findings also suggest that PMT and health belief model could be adapted as one of the models for the development of road user's evaluation and intervention. However, further study is needed to demonstrate a much better outcome as well as to ensure that the impact of the PMT in the design of evaluation and interventions give an effect to our society. Multidisciplinary research approach will be able to translate this model into a better practice.

\section{Appendix A.}

Table A.1 shows the original version of the ASDS questionnaire that used in this research. The original version was constructed in Bahasa Malaysia it is consisted of 22 demographics data and 46 attitude scale items.

\section{A.1. Original Malay version of ASDS including Cronbach's Alpha value}

\begin{tabular}{|c|c|c|}
\hline \multirow[b]{2}{*}{ No. } & \multirow[b]{2}{*}{ Question } & \multirow{2}{*}{$\begin{array}{l}\text { Cronbach's } \\
\text { Alpha if item } \\
\text { deleted }\end{array}$} \\
\hline & & \\
\hline Q1 & $\begin{array}{l}\text { Sikap pemandu yang tidak berhemah akan menyebabkan berlakunya } \\
\text { kemalangan. }\end{array}$ & .837 \\
\hline Q2 & $\begin{array}{l}\text { Saya adalah seorang pemandu berhemah yang tidak akan menyebabkan } \\
\text { kemalangan berlaku. }\end{array}$ & .831 \\
\hline Q3 & Saya sentiasa mengamalkan corak pemanduan yang berhati-hati. & .831 \\
\hline Q4 & Saya boleh menghadapi sebarang kesan dari corak pemanduan saya. & .831 \\
\hline Q5 & $\begin{array}{l}\text { Saya bersedia untuk terlibat dengan kemalangan kesan dari corak pemanduan } \\
\text { saya. }\end{array}$ & .837 \\
\hline Q6 & $\begin{array}{l}\text { Saya boleh menghadapi sebarang kemungkinan dari corak pemanduan sedia } \\
\text { ada saya. }\end{array}$ & .834 \\
\hline Q7 & $\begin{array}{l}\text { Mengubah corak pemanduan saya adalah satu halangan yang akan } \\
\text { menghadkan pergerakan saya di atas jalanraya. }\end{array}$ & .835 \\
\hline Q8 & $\begin{array}{l}\text { Mengubah corak pemanduan saya adalah satu halangan walaupun ia dapat } \\
\text { mengelakkan saya dari terlibat dengan kemalangan. }\end{array}$ & .834 \\
\hline Q9 & $\begin{array}{l}\text { Cara pemanduan saya bukanlah halangan untuk kemalangan dari berlaku } \\
\text { kerana ianya adalah takdir. }\end{array}$ & .840 \\
\hline \multirow{2}{*}{$\begin{array}{l}\text { Q10 } \\
\text { Q11 }\end{array}$} & \multirow{2}{*}{$\begin{array}{l}\text { Pemanduan berhemah dapat mengelakkan diri dari terlibat dengan kemalangan. } \\
\text { Kemalangan tidak akan dapat dielakkan jika ada pememandu lain yang tidak } \\
\text { berhemah. }\end{array}$} & .836 \\
\hline & & .835 \\
\hline
\end{tabular}


Q14 Saya mampu, untuk mengawal diri saya dari melanggar peraturan jalanraya.

Q15 Saya mampu, untuk mengawal diri saya dari menjadi pencetus kepada kemalangan.

Q16 Saya yakin boleh mengekalkan corak pemanduan saya yang baik.

Q17 Saya yakin boleh mengelakkan diri dari melakukan kesalahan jalanraya.

Q19 Terlibat dengan kemalangan akan dapat menyedarkan saya tentang bahayanya.

Q20 Kemalangan akan menyedarkan saya tentang kesilapan yang berkaitan dengannya.

Q21 Saya tidak mempunyai sebab untuk mengubah corak pemanduan saya.

Q22 Kemampuan saya mengelakkan diri dari melangar kesalahan jalanraya dapat mengurangkan peluang saya untuk terlibat dengan kemalangan.

Q23 Kemalangan jalanraya dapat dielakkan jika masyarakat mematuhi peraturan jalanraya.

Q24 Jika saya berjaya mengelakkan diri dari melangar kesalahan jalanraya, ia dapat mengelakkan orang lain dari menjadi mangsa kemalangan.

Q25 Ketika memandu, saya sentiasa mematuhi peraturan jalanraya.

Saya tidak perlu untuk memahami buku peraturan jalanraya untuk membolehkan saya memandu.

Q29 Ketika memandu, saya tidak mempunyai sebarang niat untuk melakukan sebarang kesalahan jalanraya.

Q30 Saya mempunyai niat untuk melanggar peraturan jalanraya dalam jangkamasa 12 bulan ini.

Q31 Ketika memandu, saya tidak akan melanggar peraturan jalanraya walaupun ada peluang untuk berbuat demikian.

Q32 Saya hanya akan melanggar peraturan jalanraya sekiranya saya mempunyai peluang untuk berbuat demikian.

Q33 Ketika memandu, saya tidak akan melanggar peraturan walaupun mempunyai ruang untuk berbuat demikian.

Q34 Saya akan melanggar peraturan sekiranya saya melihat ruang untuk berbuat demikian.

Q35 Banyak peluang untuk melanggar peraturan jalanraya di Malaysia, tetapi saya tetap mengamalkan corak pemanduan yang berhemah.

Banyak ruang untuk melanggar peraturan jalanraya di Malaysia, tetapi saya tetap mengamalkan corak pemanduan yang berhemah.

Q37 Saya akan terlepas dari hukuman atas kesalahan jalanraya yang saya lakukan disebabkan oleh adanya ruang yang banyak.

Q38 Saya akan terlepas dari hukuman atas kesalahan jalanraya yang saya lakukan disebabkan oleh adanya peluang yang banyak.

Q39 Saya rasa yakin untuk melanggar peraturan kerana terdapat ruang untuk melakukannya.

Q40 Saya rasa selamat untuk melanggar peraturan kerana terdapat ruang untuk melakukannya.

Q41 Saya rasa yakin untuk melanggar peraturan kerana terdapat peluang untuk melakukannya.

Q42 Saya rasa selamat untuk melanggar peraturan kerana terdapat peluang untuk melakukannya.

Q43 Saya rasa bersalah untuk melanggar peraturan walaupun ada ruang untuk melakukannya.

Q44 Saya rasa bersalah untuk melanggar peraturan walaupun ada peluang untuk 
melakukannya.

Q45 Saya tidak rasa bersalah untuk melanggar peraturan kerana semua orang akan menggunakan ruang yang ada untuk melakukannya.

Q46 Saya tidak rasa bersalah untuk melanggar peraturan kerana semua orang akan menggunakan peluang yang ada untuk melakukannya.

\section{References}

Ajzen, I. (1991). The theory of planned behavior. Organizational behavior and human decision processes, 50(2), 179-211.

Al-Naggar, R. A., Bobryshev, Y. V., \& Mohd Noor, N. A. B. (2013). Lifestyle practice among Malaysian university students. Asian Pacific journal of cancer prevention, 14(3), 1895-1903.

Bendak, S. (2005). Seat belt utilization in Saudi Arabia and its impact on road accident injuries. Accid Anal Prev, 37(2), 367-371.

Chen, C.-F. (2009). Personality, safety attitudes and risky driving behaviors-Evidence from young Taiwanese motorcyclists. Accident Analysis \& Prevention, 41(5), 963-968. doi: http://dx.doi.org/10.1016/j.aap.2009.05.013

Eiksund, S. (2009). A geographical perspective on driving attitudes and behaviour among young adults in urban and rural Norway. Safety Science, 47(4), 529-536. doi: http://dx.doi.org/10.1016/j.ssci.2008.07.034

Forward, S. E. (2009a). An assessment of what motivates road violations. Transportation research part F: traffic psychology and behaviour, 12(3), 225-234.

Forward, S. E. (2009b). The theory of planned behaviour: The role of descriptive norms and past behaviour in the prediction of drivers' intentions to violate. Transportation Research Part F: Traffic Psychology and Behaviour, 12(3), 198-207.

Ghadiri, S. M. R., Prasetijo, J., Sadullah, A. F., Hoseinpour, M., \& Sahranavard, S. (2013). Intelligent speed adaptation: Preliminary results of on-road study in Penang, Malaysia. IATSS Research, 36(2), 106-114. doi: http://dx.doi.org/10.1016/j.iatssr.2012.08.001

Goldzweig, I. A., Levine, R. S., Schlundt, D., Bradley, R., Jones, G. D., Zoorob, R. J., et al. (2013). Improving seat belt use among teen drivers: Findings from a service-learning approach. Accident Analysis \& Prevention, 59(0), 71 75.

Horvath, C., Lewis, I., \& Watson, B. (2012). The beliefs which motivate young male and female drivers to speed: A comparison of low and high intenders. Accident Analysis \& Prevention, 45(0), 334-341. doi: http://dx.doi.org/10.1016/j.aap.2011.07.023

Horvath, C., Lewis, I., \& Watson, B. (2012). Peer passenger identity and passenger pressure on young drivers' speeding intentions. Transportation research part F: traffic psychology and behaviour, 15(1), 52-64.

Iversen, H. (2004). Risk-taking attitudes and risky driving behaviour. Transportation Research Part F: Traffic Psychology and Behaviour, 7(3), 135-150. doi: http://dx.doi.org/10.1016/j.trf.2003.11.003

Masuri, M. G., Dahlan, A., Danis, A., \& Md Isa, K. A. (2014 z11, 24-26 February 2014). Public participation in shaping better Malaysian's road society in the future. Paper presented at the AicE-Bs2014Berlin Berlin, Germany.

Masuri, M. G., Dahlan, A., Danis, A., \& Md Isa, K. A. (2014 z111, 25-27 August 2014). Regeneration of Road System 
in the Urban Environment: Will Rehabilitation Components Orientate Road Users? Paper presented at the AcEBs2014Seoul, Chung-Ang University, Seoul, S. Korea.

Masuri, M. G., Isa, K. A. M., \& Tahir, M. P. M. (2012). Children, Youth and Road Environment: Road Traffic Accident. Procedia - Social and Behavioral Sciences, 38(0), 213-218. doi: http://dx.doi.org/10.1016/j.sbspro.2012.03.342

Masuri, M. G., Md Isa, K. A., \& Mohd Tahir, M. P. (2012). Children, Youth and Road Environment: Road Traffic Accident. Procedia - Social and Behavioral Sciences, 38(0), 213-218.

Masuri, M. G., Md Isa, K. A., Mohd Tahir, M. P., Hassan, H. F., Hassan, Z., Jamhuri, F. Z., et al. (2012). Behaviour Response among Health Sciences Students towards H1N1 Pandemic. Procedia - Social and Behavioral Sciences, $36(0), 77-86$.

Özkan, T., \& Lajunen, T. (2006). What causes the differences in driving between young men and women? The effects of gender roles and sex on young drivers' driving behaviour and self-assessment of skills. Transportation Research Part F: Traffic Psychology and Behaviour, 9(4), 269-277.

Scott-Parker, B., Watson, B., King, M. J., \& Hyde, M. K. (2012). Confirmatory factor analysis of the Behaviour of Young Novice Drivers Scale (BYNDS). Accident Analysis \& Prevention, 49(0), 385-391. doi: http://dx.doi.org/10.1016/j.aap.2012.02.021

Vardaki, S., \& Yannis, G. (2013). Investigating the self-reported behavior of drivers and their attitudes to traffic violations. Journal of safety research, 46, 1-11.

Wan Ahmad Kamal, W. N. H., Masuri, M. G., Dahlan, A., \& Md Isa, K. A. (2014, $26-28$ December 2014). Seat Belt Compliance and Quality of Life among Educated Young Adults in an Urban University. Paper presented at the AicEBs ver. 2: AQoL2014Istanbul

Warner, H. W., \& Åberg, L. (2008). The long-term effects of an ISA speed-warning device on drivers' speeding behaviour. Transportation Research Part F: Traffic Psychology and Behaviour, 11(2), 96-107. doi: http://dx.doi.org/10.1016/j.trf.2007.08.002

White, K. M., Hyde, M. K., Walsh, S. P., \& Watson, B. (2010). Mobile phone use while driving: An investigation of the beliefs influencing drivers' hands-free and hand-held mobile phone use. Transportation Research Part F: Traffic Psychology and Behaviour, 13(1), 9-20.

Zhou, R., Wu, C., Rau, P.-L. P., \& Zhang, W. (2009). Young driving learners' intention to use a handheld or handsfree mobile phone when driving. Transportation research part F: traffic psychology and behaviour, 12(3), 208-217. 